методы в биохимии / под ред. В. Н. Ореховича. М. : Медицина, 1977. C. $63-64$.

5. Спекторофотометрическое определение продуктов перекисного окисления липидов / под ред. проф. А. И. Карпищенко. Медицинская лабораторная диагностика (программы и алгоритмы). СПб. : «Интермедика», 1997. С. 48-52.

6. Камышников В. С. Справочник по клинико-биохимической лабораторной диагностики. Мн. : Беларусь, 2002. Т. 1. 495 с.

7. Silibor effects on cytolysis in the rat liver under $\mathrm{CCL}_{4}$ intoxication / D. Uzbekova et al. Journal of Hepatology. 2002. № 36. P. 152.

DOI https://doi.org/10.30525/978-9934-26-038-4-53

\title{
АНАЛІЗ ЗАКОНОДАВЧИХ ІНІЦИАТИВ У КОСМЕТИЧНІЙ ГАЛУЗІ УКРАЇНИ НА СУЧАСНОМУ ЕТАПІ
}

\author{
Лебединець В. О. \\ доктор фармачевтичних наук, професор, \\ професор кафедри управління, \\ економіки та забезпечення якості у фармаціі \\ Національний фармацевтичний університет \\ Казакова I. C. \\ аспірант кафедри управління, \\ економіки та забезпечення якості у фармачії \\ Національний фармацевтичний університет

\section{Казакова В. C.} \\ кандидат фармацевтичних наук, доиент, \\ дочент кафедри косметології і аромології \\ Національний фармацевтичний університет \\ м. Харків, Украӥна
}

Косметична галузь Україні на сучасному етапі знаходиться на стадії реформування. Законодавчі ініціативи у косметичній сфері направлені на виконання вимог європейських стандартів, необхідність відповідності яким визначена принципами євроінтеграції України згідно Угоди про Асоціацію між Україною та Європейським Союзом (СС) [1].

Метою дослідження був аналіз законодавчих ініціатив у косметичній галузі України та надання рекомендацій щодо ефективного впрова- 
дження сучасної законодавчої бази в сфері технічного регулювання обігу косметичної продукції на національному споживчому ринку. В якості інформаційних матеріалів використовували діючу національну і зарубіжну законодавчу базу, наукові публікації, електронні бази інформації Державного реєстру лікарських засобів України, результати власних досліджень.

Угода про асоціацію між Україною та СС декларує нагальні питання технічного регулювання. Проблематику міжнародної інтеграції України можна умовно розділити на три основні напрямки: технічне співробітництво між Україною та ЄС; гармонізація технічних регламентів, стандартів і процедур оцінки відповідності; укладення угоди про оцінку відповідності та прийнятності промислових товарів(Agreement on Conformity Assessment and Acceptance of Industrial Goods (ACAA). АСАА передбачає гармонізацію технічних регламентів, стандартів i процедур оцінки відповідності країн-учасниць відповідно до вимог законодавства СС. Наведені напрямки міжнародного співробітництва $€$ також актуальними для косметичної галузі України і передбачають ряд взаємних умов - обов'язковість відповідності українського законодавства в сфері технічного регулювання базовим законодавчим актам $\mathrm{CC}$, визнання сертифікатів та результатів випробувань [2]. У рамках євроінтеграції в останні роки Україною було прийнято низку законів: Закон «Про стандартизацію» від 5 червня 2014 р № 1315-VII, Закон України «Про технічні регламенти та оцінки відповідності» від 15 січня 2015 р. № 124-VIII. Також за вимогами Угоди, Україна зобов'язана гармонізувати технічні регламенти відповідно до вимог ЄС. Затвердження Технічного Регламенту на косметичну продукцію в Україні спрямоване також направлене на виконання зобов'язань Угоди про Асоціацію, і при цьому дозволить косметичній продукції українського виробництва конкурувати із закордонною косметикою на зовнішніх ринках. Наразі Технічний регламент на косметичну продукцію, гармонізований з нормами Регламенту ЄС № 1223 / 2009, принятий Постановою Кабінету Міністрів України 20 січня 2021p. [3]. Документом передбачені вимоги до косметичної продукції та визначено перелік із 1 тис. 383 заборонених для використання в косметичній продукції речовин. Також регламент містить перелік речовин, дозволених до використання в косметичній продукції з урахуванням встановлених обмежень, а також список барвників, консервантів і УФ-фільтрів, які будуть дозволені до використання в косметичній продукції. Крім того, встановлені вимоги до канцерогенів і наноматеріалів, що можуть міститися у косметичних продуктах. Оцінка безпеки косметичної продукції, згідно з вимогами документу, передбачає комплекс заходів, спрямованих на доказ ії ефективності і безпеки для людини. Проведення експертизи повинен забезпе- 
чувати експерт 3 повною вищою освітою (спеціаліст, магістр) за напрямом підготовки «Медицина» або «Фармація». При документуванні процесу ввезення косметичної продукції на територію України, уповноважена (відповідальне) особа повинна зберігати документацію на таку продукцію протягом наступних 10 років після введення в експлуатацію останньої партії такої продукції. Документація повинна включати:

- опис косметичної продукції;

- звіт про оцінку відповідності;

- опис методів виробництва і заяву відповідно до норм належної виробничої практики (Good Manufacturing Practice - GMP);

- підтвердження заявленої ефективності косметичної продукції;

- інформація про будь-яких проведених дослідах на тваринах.

Для ввезення та реалізації косметичної продукції на території України відповідальна особа повинна нотифікувати наступну інформацію:

- категорії косметичної продукції та їх найменування;

- найменування та місцезнаходження відповідальної особи;

- країну походження;

- контактні дані відповідальної особи для зв'язку в разі необхідності;

- наявність у складі продукції УФ-фільтрів, наноматеріалів, канцерогенів, мутагенних і токсичних речовин і їх ідентифікація;

- рамку рецептури, яка враховується при наданні першої медичної допомоги і в невідкладних випадках.

Наведені вимоги відповідають основним положенням Регламенту ЄC №1223/2009 [4; 5] та мають на меті забезпечити споживачеві якісний, безпечний та ефективний косметичний продукт, якій буде мати право обігу на споживчому ринку усього європейського простору.

3 прийняттям Технічного регламенту на косметичну продукцію функції державного ринкового нагляду за косметикою будуть покладені на Державну службу України з лікарських засобів та контролю за наркотиками. Обов'язкове застосування Технічного регламенту передбачається після так званого перехідного періоду протягом 18 місяців після його опублікування.

Для ефективної реалізації Регламенту виникає питання імплементації його вимог в Україні, а саме:

- створення української нормативно-правової бази;

- адаптація нормативних документів до існуючої законодавчої системі;

- визначення компетентних організацій, які забезпечать контроль їх виконання. 
Актуальність вищезазначених висновків підтверджена результатами досліджень сучасного стану нормативно-правового забезпечення у сфері обігу косметичної продукції на сучасному споживчому ринку України [6; 7].

На основі аналізу діючої національної законодавчої бази та досвіду зарубіжних країн з регулювання обігу косметичної продукції [8], нами розроблені рекомендації по реалізації Технічного регламенту. Для його ефективного впровадження нами запропонований алгоритм відповідних заходів:

- розробити План дій щодо впровадження Технічного Регламенту на косметичну продукцію;

- передбачити приведення існуючих нормативно-правових актів, що регламентують обіг косметичної продукції, у відповідність до Регламенту на косметичну продукцію;

- визначити компетентні організації, уповноважені на контроль виконання вимог Регламенту на косметичну продукцію;

- розробити і затвердити у встановленому порядку національні стандарти з метою забезпечення їх відповідності європейським нормам;

- забезпечити системне внесення доповнень і змін до переліку інгредієнтів, що регламентуються додатками Технічного регламенту;

- створити відповідну системи інфраструктури якості косметичної продукції.

За результатами проведених досліджень можна сформулювати наступні висновки:

- За даними аналізу діючої національної та зарубіжної законодавчої бази, присвяченій питанням євроінтеграції України і регулюванню обігу косметичної продукції на споживчому ринку, визначено актуальність проблематики технічного регулювання обороту косметичної продукції.

- Розроблено алгоритм відповідних заходів щодо ефективної реалізації Технічного регламенту на косметичну продукцію 3 метою забезпечення відповідності європейським нормам і сучасним тенденціям розвитку косметичної індустрії.

\section{Література:}

1. Георгієвській Г. В. Основні тенденції у гармонізації вимог виробництва и контролю якості косметологічних засобів в Україні з вимогами СС у світлі членства України в Свропейській Фармакопеї. Фармаком. 2016. № 4. С. 21-28.

2. Безпека косметичний товарів в Україні. Медико-правові аспекти та сучасна кон'юнктура на внутрішньому ринку / О. М. Ковальова, 
О. М. Цігульова, О. М. Шуміло, О.О. Дєєва. - Київ: ФОП «Клименко», 2016. - 447 c.

3. Уряд затвердив Технічний регламент на косметичну продукцію. URL: https: //www.apteka.ua/article/580989. (Дата звернення: 20.02.2021).

4. US and EU Cosmetics Regulation. URL: https://cosmeticsinfo.org/ cosmetics-regulation (Date of access: 05.01.2021).

5. Regulation (EC) No 1223/2009. European parliament and of the council of 30 November 2009 on cosmetic products. Official Journal of the European Union. 2009. P. L 342 / 59 L 342/209.

6. Kazakova Iryna, Viacheslav Lebedynets. Analysis of the state of technical regulation of turnover of cosmetic productions in Ukraine. ScienceRise. 2020. № 2(67). P. 19-26.

7. Казакова I.C., Лебединець В.О. Аналіз та визначення перспектив розвитку ринку лікарських косметичних косметичних засобів в Україні. Соціальна фармачія в охороні здоров 'я. 2020. Т. 6. № 2. С. 44-60.

8. Казакова І.С., Лебединець В.О., Казакова В.С. Проблематика стандартизації лікарських косметичних засобів в Україні. Вісник фармації. 2020. № 2(100). C. 84-94.

DOI https://doi.org/10.30525/978-9934-26-038-4-54

\title{
DETERMINATION OF FRUCTANS CONTENT IN SOME PLANT ANTIDIABEIC MIXTURES
}

\author{
Savych A. O. \\ Candidate of Pharmacy (Ph.D.), \\ Assistant Professor at the Department \\ of Pharnacognosy with Medical Botany \\ Ivan Horbachevsky Ternopil National Medical University \\ of the Ministry of Health of Ukraine \\ Marchyshyn S. M. \\ Doctor of Pharmacy (Dr. Habil.), Professor, \\ Head of the Department of Pharnacognosy with Medical Botany \\ Ivan Horbachevsky Ternopil National Medical University \\ of the Ministry of Health of Ukraine \\ Ternopil, Ukraine
}

Diabetes mellitus is one of WHO's priority issues. It requires immediate resolution as the epidemiological situation is gaining alarming proportions - 